DOI: $10.17516 / 1997-1370-0559$

УДК 811.11 ’01:81’22

\title{
Interpretations of the Mythologeme
} "Tree-Cross" in Old English

\author{
Sergei G. Proskurin a,b and Anna V. Proskurinab \\ ${ }^{a}$ Novosibirsk National Research State University \\ Novosibirsk, Russian Federation \\ ${ }^{b}$ Novosibirsk State Technical University \\ Novosibirsk, Russian Federation
}

Received 24.08.2019, received in revised form 12.01.2020, accepted 06.03.2020

\begin{abstract}
The topicality of the appeal to the interpretation of a tree-cross mythologeme is caused by the change of the pagan worldview into Christian. The development of ideas about the Christian sign is complex, in one of the approaches to transforming the treecross, a part of the overcome ideas about the world as space around the world axis is preserved, i.e. the world tree. The coming era of Christianity inherits this view, and the cross itself appears as a world axis that defines the coordinates of space. The purpose of the article is to show the evolutionary semiotic row, which represents both Christian and pagan symbolism. Initially, the cross appears as a motivated view. Then the terms of the denotative plan appear, devoid of pagan connotations of the tree-cross type.

In general, in the evolution of the term continuity is traced, one designation is replaced by another. For some time, the second item copies the functions and forms of the first, replacing it in the subject line. The cross as an object of worship in Christianity replaces the world tree. All new nominations of the cross are associated with the motivation of the world as the center where the altar is installed, which was initially presented in the tradition as a world tree, and then became designated by the cross. The cross, as the main Christian symbol, often appears as made of wood and is identified with the cosmic world tree growing directly into heaven. Research methods which are used in this article are as follows: philological analysis of the text and semiotic analysis of texts. The set of communicatively relevant factors that determine the statement, as well as the situational and contextual relevance of the lexical meaning, are taken into account. In turn, the necessary initial amount of communicatively relevant information is obtained on the basis of linguistic methods. In particular, data from an etymological analysis are involved. The research material was provided by the Old English written monuments accessible to the modern researcher. Texts in other Indo-European languages are occasionally referred; they act as a background showing some parallels.
\end{abstract}

Keywords: cross, world tree, evolutionary semiotic series, paganism, Christianity, mythologeme.

\footnotetext{
(C) Siberian Federal University. All rights reserved

* Corresponding author E-mail address: s.proskurin@mail.ru, a.vyacheslavovna@gmail.com ORCID: 0000-0001-7244-264X (Proskurin); 0000-0001-9026-2511 (Proskurina)
} 
Research area: linguistics.

Citation: Proskurin, S.G., Proskurina, A.V. (2020). Interpretations of the mythologeme "tree-cross" in Old English. J. Sib. Fed. Univ. Humanit. Soc. Sci., 13(3), 316-326. DOI: 10.17516/1997-1370-0559.

\section{Introduction}

The mythologeme is a universal concept of something, extracted from the mythopoetic tradition. Thus, mythopoetic interpretations of the world reveal the central mythologeme of the world tree. The tree stands in the center of the archaic cosmos and determines the coordinates of space. At the same time, the tree transforms into a cross. "Seth goes to paradise for the oil of mercy, sees a tall, dry tree there among the greenery: this is the desired oil, the angel tells him. Adam enlightened the prophetic meaning of these words given to him by Seth, and himself condemns that the tree of life will grow on his grave. Further, Iericho, the son of Noah, transplanted this tree from Hebron, where Adam was buried, to Lebanon - and the familiar auto details follow. But the legend of the cross in Calderon's play is not limited to this: at the end of the flood, the dove brought Noah an oil branch (no one knows where) which he planted in Lebanon. A tree that grew out of it and seemed at the same time a palm tree, cedar and cypress, is surrounded by a general honor. Felled and unsuitable for the construction of the temple, it is thrown in the garden, and then serves as a bridge to the mountain where the Adam's head is buried (= Golgotha). On this trunk, which Solomon decides to protect as the greatest treasure, the Messiah will suffer" (Veselovskii, 2006: 333). This extract from the plot of Calderón's play "La Sibila del Oriente y Gran Reina de Saba" shows the desired transformation. The transformation of the symbolic code "tree" > "cross" is universal for cultures emerging from shamanism and experiencing the influence of the Christian worldview. So, according to Mosco Moskov, the sign of the god Tengri $\mathrm{Y}$ in the Turkic area, which also originally denoted a tree, later serves as the basis for the image of the cross in the ancient Bulgarian Christian tradition (Proskurin, Tsentner, 2009) (Fig. 1).

The transformation of the sign is associated with the linguistic-cultural transfer in the tradition. After the adoption of Christianity, the sign of the god Tengri, which also denotes a tree, turns into a sign of the cross. As a Bulgarian researcher showed, a runic record of the Tengri name, consisting of four characters, a polygram, is gradually transformed by reduction into a monogram, which eventually becomes an ideogram. This final character has the following form: [Y].

The given sign in the context of the ancient Bulgarian culture exists as a symbol of the supreme deity, a magic sign, a talisman. With the adoption of Christianity, it turns into a sign of the cross - this process is sequentially restored according to archaeological data and images on amulets. Moreover, the final sign - a cross or a double cross - can be interpreted in two ways: either as the addition of a fork at each of the four ends of the cross, or as the addition at the central point of the four Tengri signs, the "four little Y".

We find the most interesting example of such a record of the cross when analyzing the inscription of the Bulgarian king Samuel dating back to 993 (Khaburgaev, 1986: 40). In the outline of the inscription, the Y-shaped elements of the cross are clearly visible, originally meaning the world tree. So, in the semiotic evolutionary

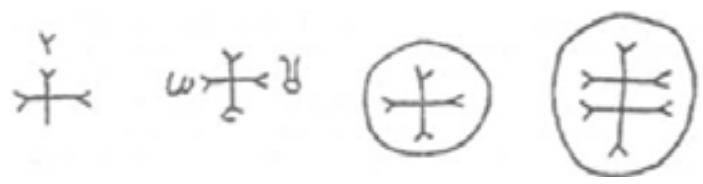

Fig. 1. Transformation tree-cross in Old Bulgarian tradition 
rows, the "tree" - "cross", the second item - the deputy - retains the characterological features of the first in its appearance (Campbell, 2004: 249; Peirce, 1985). The evolutionary parameters of the transition "tree-cross" are found in the Old English tradition. The research material was provided by the Old English written monuments accessible to the modern researcher. Thus, this work analyzes the linguistic-cultural transfer, or transfer of information in time and space.

\section{Linguocultural transfer wood-cross}

\subsection{Linguocultural transfer} in world traditions

The linguocultural transfer "world tree" "cross" is found in a number of traditions. This identification of the cross with the World Axis is clearly expressed in the motto of the Carthusian monks "Star Crux dum volvitur orbis" (The cross stands, while the world rotates) (Guénon, 2008: 210). The symbol "Power", where the cross crowning the Pole, takes the place of the axis (Fig. 2).

In Chinese symbolism, a tree is known which ends are connected in pairs, depicting a synthesis of opposites or a resolution of duality in unity. Thus, a single tree is obtained, the branches of which are divided and reconnected at their ends (Fig. 3), there are three-lobed leaves connected with two branches at the same time, and cup-shaped flowers $<\ldots>$ are a process of universal manifestation: everything proceeds from unity and returns to unity; duality arises in the interval - separation or dif-

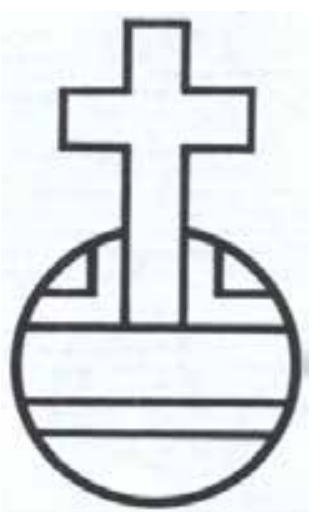

Fig. 2. The Cross victorious ferentiation, the result of which is the phase of manifest existence; the ideas of unity and duality, therefore, are united here, as in other images (Guénon, 2008: 211).

One of the variants of the world tree is its Christian image of a flourishing tree. Henry Suso (1295-1366) is an outstanding early German mystic whose mystical visions abounded in symbolic images. He called himself the "Servant of Eternal Wisdom," identified with Christ. The cited illustration (Fig. 4) (painted woodcut) is taken from the book "Das Buch gennant Seuse" (1482), which contains all of his main works.

Jesus Christ is crucified on a tree full of roses, six half-figures of angels and saints above it. A rose was for Suso as a symbol of special importance. It is believed that he was the first to introduce it as a symbol of the passions of Christ.

The vertical line of the cross - the image of the World axis - represents the trunk of the Tree, while the horizontal line forms its branches. This Tree rises in the center of the world in biblical symbolism, in particular, it is the Tree of life growing in the midst of earthly Paradise, which itself represents the center of our world (Guénon, 2008: 212-213).

Thus, the tree-cross mythologeme is opposed to the denotative designations of the cross that do not bear evolutionary implications. What designations appeared first (see: (Proskurin, Feshchenko, 2019).

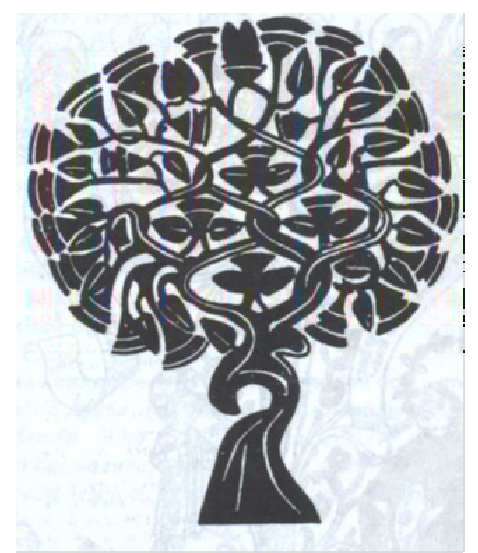

Fig. 3. Chinese depiction of the world tree: every branch (Yin and Yang) generates a flower, the common beginning 


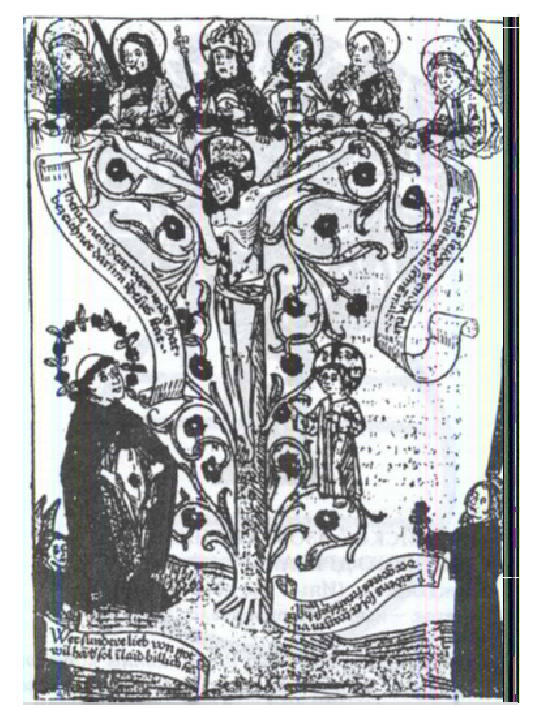

Fig. 4. Cross as a thriving tree

\subsection{Linguocultural transfer in the Anglo-Saxon tradition}

Initially the cross appears as a motivated representation, i.e. explained, besnaedan twigum and telgum and beh taken wesan (Dan. 515-516) "cut off branches, and there will be a cross". According to other German notions, the cross is a sprouted world tree (mittilo boum letters. "Middle tree", preserving the cosmic function of the link between the underworld, earth and heaven. In medieval studies, the "world tree concept" undergoes a metamorphosis. It often refers to an "inverted tree" (Lat. Arbor inversa), growing from heaven to earth: "Its roots are in heaven, and its branches are on earth." Here we see an example of a semiotic evolutionary row (the term, like the concept, was introduced into semiotics by Yu.S. Stepanov), when in continuity is traced in the evolution of objects, one object replaces another and becomes the heir to its functions). For some time, the second item can copy the functions and forms of the first, replacing it in the subject line (cf.: the cross as a worship item in Christianity replaces the tree of the world) (Proskurin, 2010).

Along with motivated designations, denotative (unmotivated) designations are also found. Such a lexeme is the Old English neologism cross. After the adoption of Christianity, words with the meaning "tree-cross" are replaced by a neutral borrowing cross ("cross"), which has no pagan connotations. Three sources of borrowing the word cross are currently being discussed: 1. crux (Latin word); 2. cros (Norman word, previously borrowed from Latin, crux); 3.cros (an Irish word that was included in the vocabulary of the English language thanks to Irish missionaries) (Crystal, 2004: 31). The information transfer factor, excluding pagan connotations, influenced the choice of the word cross ("cross") in the English Christian culture (Proskurin, 2015).

Pagan connotations influenced the choice of lexical means for designating the cross in the Old English tradition. So, the cross is often referred to as a tree, with evolutionary implications: sigebēam ("victory tree"), syllicre trēow ("best tree"), bēam (a) beorhtost ("brightest tree"), holtwudu ("tree from the forest"), wealdendes trēow ("the tree of the Lord", "the tree of the Savior"), wudu seelesta ("a very good tree"), wuldres bēam ("the tree of glory"). In the Old English period, there were designations of the cross as a sign, symbol täcen, $r \bar{o} d$, which are also motivated by the fact that they included the implication of a tree. We give an example from the Old English poem "Visions of the Cross", where the implications are especially obvious (the orig- 
inal text of the poem is presented by: (Baker, 2007: 241):

\section{The Dream of the Rood}

$<\ldots>$ Onġyrede hine pā ġeong hæleð - pæt wæs God ælmihtig, hēanne,

strang ond stīðmōd. Gestāh hē on gealgan

mōdig on manig̀ra ġesyhðe, pā hē wolde mancyn lȳsan.

Bifode ic pā mē se beorn ymbclypte. $\mathrm{Ne}$ dorste ic hwæðre būgan tō eorðan,

feallan tō foldan scēatum, ac ic sceolde fæste standan.

Rōd wæs ic̀ ārǣred <..>

$<\ldots>\bar{A} h o ̄ f$ ic̀ rīcne Cyning,

heofona Hlāford, hyldan mē ne dorste. Purhdrifan hī mē mid deorcan næg்lum. On mē syndon $p a \bar{~}$ dolg ġesīene

opene inwidhlemmas. Ne dorste ic hira nǣnigum sceððan.

Bysmeredon hīe unc būtū ætgædere. Eall ic wæs mid blōde bestēmed,

begoten of pæs guman sīdan siððan hē hæfde his gāst onsended $<\ldots>$

$<\ldots>$ Crist wæs on rōde.

Hwæðere pǣr fūse feorran cwōman

tō pām æðelinge; ic̀ pæt eall behēold.

Sāre ic̀ wæs mid sorgum gedrēfed; hnāg ic̀ hwæðre pām secgum tō handa,

ēaðmōd, elne myċle.

$<\ldots>$ Eall ic wæs mid strǣlum forwundod.

Ālēdon hīe ðǣr limwērig̀ne, gestōdon him æt his līeses hēafdum;

behēoldon hīe ðǣr heofenes Dryhten <...>

The cumulative properties of language as a part of culture ensure the preservation in the texts of representations of the preliterate (for Germanic peoples, pre-Christian) period. Traces of pagan beliefs are often preserved in early Christian texts in Old Germanic languages, including translations from Latin, and are of a formulaic nature (Proskurin, Tsentner, 2009: 172). So, there is a layering of the new, Christian picture of the world on the old, pagan one. These stratifications entail the interweaving of pagan images in the Christian text in order to adapt them to understanding in accordance with the characteristics of the recipient culture (Proskurin, 2013a, 2013b; Watkins, 1987, 1995).

It is noteworthy that this text does not exclude pagan connotations. So, in the poem, the cross is called as follows: syllicre trēow ("the best tree"), bēam (a) beorhtost ("the brightest tree"), bēacen ("appearance"), eaxlegespan ("transverse beam"), gallows ("gallows"), Sigebēam ("tree of victory"), wealdendes trēow ("tree of the Lord", "tree of the Savior"), wudu sēlesta ("very good tree"), rōd ("cross"), holtwudu ("tree from the forest") , wuldres bēam ("tree of glory"), gealgtrēow ("tree for the gallows"). Jesus Christ is called: Drihten ("Lord"), God ælmihtih ("Almighty God"), Cyning ("Leader"), heofona Hlāford ("Lord of the Heavens"), beorn ("Warrior"), Crist ("Christ"), Nealdend ("Lord"), Anweatda ("Lord").

The presence of pagan connotations in the text indicates the imposition of a Christian worldview on the pagan picture of the world. So, the wooden cross in this work has the ability to feel and speak. It is, as it were, the retinue of the Leader (Jesus Christ). It should be noted that in ancient German (pagan) culture, fidelity to their leader was especially valued. "If it came to a fight, it's shameful for the leader to yield to someone in valor, and it's shameful for the squad not to become like the valor of the leader. And to come out alive from the battle in which the leader fell is dishonor and shame for life; to protect him, to perform valiant deeds, thinking only of his glory, is their first duty: leaders fight for victory, warriors fight for their leader (Tacitus, 2010: 452). It is possible that at the dawn of Christianity for a smooth transition from paganism to the image of Jesus Christ was presented to Christianity as the image of a leader (cf. Cyning ("Leader"), heofona Hlāford ("Lord of heaven"), beorn ("Warrior"), Anweatda ("Lord")), and believers appeared to be his warriors. The German form *drauxti-naz (*druktinos), according to É. Benveniste, is a secondary term that serves to nominate a person who is at the head of a social group (Benveniste, 1995: 88). As researcher S.V. San- 
nikov notes, the concept of "eldormen", which can be found in the "Anglo-Saxon Chronicle", is an analogue of the term "leader" (Sannikov, 2009).

Ancient Germans chose kings from the most noble people, and leaders from the most valiant. However, kings did not possess unlimited power; it was the leaders who ruled over them, captivating and admiring them with their examples (Tacitus, 2010: 449). In Germanic languages, this type of word formation is presented in several important derivatives: Gothic piudans (from *teuta-nos) "king, head of the community", kindins (from *genti-nos) "head" (gens) - they are parallel to lat. tribūnus from tribus. In the Old English dryhten "lord" (in the Christian texts "Lord") the form * drukti-nos "leader drukti" is reflected. Such a hierarchy was characteristic of ancient German society (Benveniste, 1995: 88-89). These examples indicate that, perhaps, to introduce and consolidate the Christian faith among the ancient Germans, Christ appeared to them as the leader of the tribe. Over time, on the island of Britain, the image of Christ came to the fore, while maintaining a pagan connotation. We also indicate that at one time J. Grimm noted (Grimm, 1844-1854) that Christ was perceived in the early stages of Christianization as the ancient German god of storms, thunder and fertility Thor, whose equipment included the Mjolnir hammer. In this case, the hammer imitates the cross.

An analysis of the religious factor in the formation of the early forms of royal power among Germanic peoples is necessary to clarify the essence of the phenomenon of royal power, to understand the process of its transformation from the institution of tribal military leadership to the institution of early statehood (Sannikov, 2009: 51). Starting from V to $\mathrm{X}$ centuries Christianity spreads throughout Europe, and the place of ancient myths telling of warlike gods is occupied by gospel ideas about the Savior and Creator. The king appears to the people of that time as the "vicar of Christ", since he maintains his high position as the supreme religious leader and defines the religious preferences of his peoples. The new faith was attractive to Europeans due to the fact that it gave life and death a positive meaning, in other words, explained the hardships and secrets of life.

It is worth noting that Christianity also influenced German legal institutions. Thus, the new faith prompted the "governors of Christ" to write down laws in the form of short codes. German codes show the implementation of Christian concepts - the initial equality of each before the Creator. Brief laws helped prevent blood feuds and maintain peace.

Considering the semiotic aspect of communication, we can assume that the communicative task was based on the fact that new information was understood through its transmission in the framework of the old image, already known to native speakers. Communication was based on a sociocultural base thanks to interindividual psychology. Thus, replacing the central cosmic symbol of the world tree with a cross that retains the features of a pagan symbol is an example of accessible communication. The task of transmitting information over time is to transmit information on an important Christian element of culture - the cross as a symbol of Christianity. The pagan image of the world tree is not at all important from the point of view of the semiotic aspect of information transfer, but it is important from the point of view of communication in the generation of Germans who have just adopted Christianity (Proskurina, 2018).

\section{Center for the world as motivation of space in mythopoetic tradition}

All these nominations of the cross are associated with the motivation of the world as the center where the altar is installed, which was originally presented in the tradition as a world tree, and then became designated by the cross. One example of the implementation of the concept of "world" in ancient Germanic culture is the common German * midja (n) -gardaz - letters. "Middle fenced space" or more precisely "middle of the fenced space". In turn, these data, obtained on a linguistic basis, directly connect the origin of ancient German words with the meaning "middle world", with the symbolism of the central point of the world - the center in general, the cultural universal, typical in the 
mythological traditions of different peoples. In the mythopoetic tradition, the center is always a region of the highest sacred, a region of absolute reality. Based on the polysemantic nature of *midja (n) -gardaz turnover in diachrony, we do not exclude "ambivalence" in the principle of composite nomination, which presumably suggests the possibility of a second reading of "middle enclosed space" (the Midgard concept) (Proskurin, 2010).

However it is the sacred nature of the central point of the world that makes it possible to understand the metonymic transfer of this term to the designation of "the world in general" and thus combine the two named concepts. The restored picture of the preliterate period testifies to this: the center of the ancient Germanic world coincides with the center of sacred objects inscribed into each other (center, fenced place, etc.), demonstrating the heterogeneity and non-isotropy of the archaic cosmos (compare the typological diagram of the mythopoetic space of various cultures: the sacrifice on the altar in the center - the temple - his settlement - his own country, etc.).

In the written tradition, the "middle" "tree" relationship, reconstructed for the Indo-European era, implicitly preserved in the Anglo-Saxon name of the "middle world", is indirectly reflected in the early Anglo-Saxon Christian monument "Daniel A", which contains a fragment about the "world tree" of the Germanic peoples. From the point of view of the poetic form, this fragment is an autonomous poetic text, a sample of ancient alliterated tonic:

on foldan faegre stode wudubeam wlitig, se waes wyrtum faest beorht on blaedum naes he bearwe gelic ac he hlifode to heofontunglum swilce he oferfaethmde foldan sceatas, ealne middangeard oth merestreamas, twigum and telgum (Dan. A. 498-504).

Two oppositions are noted in the text: "internal" - "external" ("habitable space" - "sea") and "lower" - "middle" - "upper". The sacred significant central place of the world is occupied by the wudubeam tree (compare lithua- nian vidurys - "middle"), which crown extends over the world, restricting it horizontally, the trunk represents the world vertically, the root is a symbol of the bottom.

Despite the fact that such a view is fixed in the written tradition, the researcher has the necessary Indo-European material, suggesting that the specified text coincides in content with the most profound reconstruction of the Indo-European ideas about the world. In a later Old English poem, "The Dream of the Rood," the cross - beam (literal "tree") - appears as the central cosmic symbol connecting the "middle world" with heaven and determining the coordinates of space. In the extracted fragment of the description of the "tree-cross", the alliterative connections of the hemistiches in the verse are "relict", unusual for the text of the poem as a whole. In turn, this contributes to the inclusion of the description of the Christian sign - the cross - in the fabric of ancient German poetry and its interpretati on through tradition:

on lyfte laedan leohte bewunden beam beorhtost eall paet

beacen waesbegoten mid golde

gimmas stodon faegre aet sceatum $[\ldots]$.

He pa on heofenas astag;

hiđer eft on pysne middangeard mancyn secan (D. R. 4-7, 104-105).

In contrast to the contextual meaning in "Daniel" (see above), here in the middangeard concept the connection "lower" - "middle" "upper", which dominates the Christian worldview, is updated. In general, the code of the world can be considered (and is being considered) in its symbolic, semiotic aspect. However, there is such a variety of encoded information when the object is reflected in the code word -a sign of the real world. Such symbolic semiotic codes in culture include the concept of a "tree" as a symbol of the pagan world, a cross as an object of Christian culture, etc.

\section{Conclusion}

In the semiotic code, the semiotic evolutionary series of objects is often actually represented, built on the principle of following 


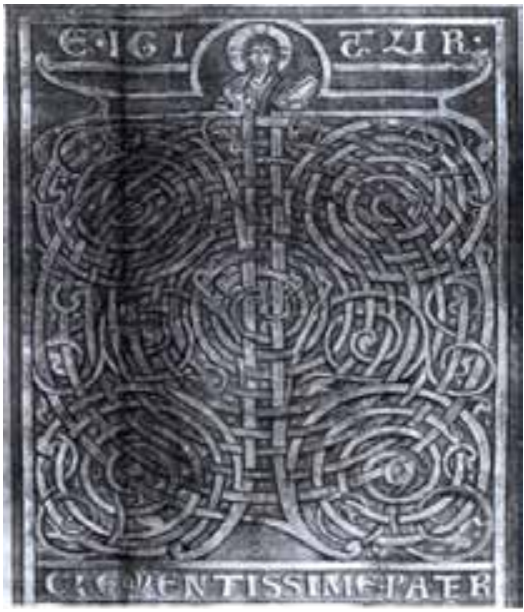

Fig. 5. Cross as a thriving tree or the fabric of the universe

these objects in history. One item is replaced by another item performing the functionally the same role. Over a period of time, the second item mimics the shape and characteristics of the first item. This important semiotic phenomenon is associated with the accumulative nature of human culture. So, for some time, the substitute item retains the characteristics of the item being replaced. In one evolutionary row, you can compare the carriage and the coupe, which at the beginning of its history directly copies the carriage, or rather a series of carriages located on the same platform. It retained this semiotic attribute to this day. In the semiotic evolutionary series, the carriage precedes the coupe, but the semiotic line of the carriage is relevant when creating another vehicle $-\mathrm{a}$ car, and is preserved in its structure (as a relic). We often encounter similar transformations in culture.

In any culture, there is one feature - objects and elements of culture usually form chains in the history in which some objects and elements replace others with the development of ideas, technologies and civilization. In the history of Indo-European pictures of the world, particular attention is paid to the change of the central cosmic symbol of the "world tree" with a cross, which plays the most important symbolic role in the new worldview - Christianity. These objects form evolutionary rows with their names when one concept (denotation word) replaces another concept (denotation word) in the evolutionary semiotic series of central cosmic symbols.

The cross, as the main Christian symbol, often appears made of wood and is identified with the cosmic world tree growing directly into heaven. Most liturgical texts compare the cross with a pillar, mountain or staircase. Thus, the center of the world is part of the Christian picture of the world. It is worth noting that the image of the cross in the early Christian literature was presented as follows: four branches of the cross were associated with four dimensions of world space (width, long, high, depth (Lat. latitudo, longitudo, altitudo, profondum)). The cross itself was represented by the image of the crucified Christ, and its dimensions were associated with the position of the head, hands and body of the Savior. Mostly stable associations formed between the span of the hands of Christ and the width (latitudo) of the cross.

Let us give an example of the synthesis of images of the world tree and the cross. In the manuscript of the late $12^{\text {th }}$ century Berthold Missal - "The Cross - A Prosperous Tree or Fabric of the Universe" The cross appears as a flourishing tree. Megalithic circles and spirals are visible on the manuscript, which represent the image of a world tree (more precisely, two trees) and at the same time the Prosperous Cross. Christ crowning the world axis is depicted on the upper branch. Under the horizontal crossbeam of the cross separating the upper from the lobar, there is a serpent, with the right rings around the double trunk of the Tree and four branches extending from it, also twisted into regular spirals, with graceful leaves of shoots. All lines are intertwined in the correct order, forming the "Universe fabric" according to the mandala pattern (Guénon, 2008: 226227) (Fig. 5 by: (Guénon, 2008: 226-227)):

In this context the world tree represents the "world axis", and the snake symbolizes the totality of cycles of universal manifestation. In this case, the snake represents danger and malignancy. He illustrates his involvement in an endless series of cycles of manifestation. The role of the snake is to preserve the symbols of immortality, to which it blocks access. 
For example, he wound himself in a Colchis grove around the Tree of Life, on which a golden fleece was hung, or in the Hesperides garden, around a tree with apples (Guénon, 2008: 129-130).

Thus, the idea of the cross in the Old English mythologeme is stratified into three parts. The first of these refers to the cross as a geometric figure. On the other hand, evolutionary ideas about the cross as a tree dominate, i.e. as a cosmic symbol. There is also a third association connected with the alphabet, which we find in Rabanus Maurus's work (De laudibus sanctae crucis. PL 107.154):
In crus namque, quae iuxta caput posita est, sunt tres litterae, hoc est

A, $M, \Omega$ et quod significat initium et finem.

On the cross, in the place where the head is, there are three letters - A, M, $\Omega$ (omega), which means the beginning and the end (Proskurin, 2014).

Consequently, the variability of the designations of the cross is largely predetermined by the prevailing tradition. In developed Christianity evolutionary implications look redundant and gradually disappear from literature.

\section{References}

Baker Peter, S. (2007). Introduction to Old English. Malden, MA: Blackwell Pub, 388 p.

Benveniste, É. (1995). Slovar' indoevropeyskikh sotsial'nykh terminov [Le vocabulaire des institutions indo-européennes]. Moscow, 456 p.

Campbell, J. (2004). Mificheskii obraz [The Mythic Image]. Moscow, 683 p.

Crystall, D. (2004). The Stories of English. London: Penguin books, 584 p.

Grimm, J. (1844-1854). Deutsche Mythologie. Göttingen, Bd. 1-2.

Guénon, R. (2008). Simvolika kresta [The Symbolism of the Cross]. Moscow, 704 p.

Khaburgaev, A.G. (1986). Staroslavyanskii iazyk [The Old Slavic Language]. Moscow, 288 p.

Peirce, Ch.S. (1985). Logic as Semiotics: The Theory of Signs. Semiotics: Introductory Anthology (Ed. R. Innis), Bloomington, 4-23.

Proskurin, S.G. (2010). Essays in Contemporary Semiotics. Toronto: LEGAS, 99 p.

Proskurin, S.G. (2010). The role of matrices in preserving non-genetic data. In Semiotica, Issue 182, 397-408, ISSN (Online) 1613-3692, ISSN (Print) 0037-1998.

Proskurin, S.G. (2013a). To the question of a topical network of language and culture. In Semiotics 2012: semiotics and the new media: proc. of the 37 annu. meet. Ottawa, Canada, 1-4 Nov. 2012. Ottawa: Legas, 125-132.

Proskurin, S.G. (2013b). The evolutionary semiotic row. Why Semiotics? 38 annu. meet. of the semiotic soc. of America, USA, Dayton, 24-27 Oct. 2013, 35.

Proskurin, S.G. (2014). Semiotics and the ABC Principle Semiotics 2013: why semiotics? eds.: J. Pelkey, L.G. Sbrocchi, Legas Publ, 67-80. ISBN-13: 978-1-897493-53-3.

Proskurin, S.G. (2015). Early biblical semiotics in Britain. Semiotics 2014: the semiotics of paradox. Toronto: Legas, 539-542. ISBN 978-1-897493-58-8.

Proskurin, S.G., Tsentner, A.S. (2009). K predystorii pis'mennoi kul'tury: arkhaicheskaia semiotika indoevropeitsev [To the Prehistory of Written Culture: Archaic Semiotics of Indo-Europeans]. Novosibirsk, 196 p.

Proskurin, S.G., Feshchenko V.V. (2019). Voice and bodily deixis as manifestation of performativity in written texts. In Semiotica, Vol. 2019, iss. 227, 317-334. DOI: 10.1515/sem-2017-0133.

Proskurina, A.V. (2018). Religious concepts in the Old English Tradition. Cross-Inter-Multi-Trans: proc. of the 13 World congr. of the intern. assoc. for semiotic studies (IASS/AIS), Lithuania, Kaunas, Technologija, 267-275. ISBN 978-609-02-1554-8. Available at: http://iass-ais.org/wp-content/uploads/2019/01/ CrossInterMultiTrans_Proceedings.pdf

Sannikov, S.V. (2009). Obrazy korolevskoi vlasti epokhi Velikogo pereseleniia narodov v rannesrednevekovoi zapadnoevropeiskoi istoriografii [The images of king's power of the epock of people's migration in the early medieval western European historiography]. Novosibirsk, 212 p. 
Tacitus, C. (2010). Annaly. Malye proizvedeniia [Annales]. Moscow, 505 p.

Veselovskii, A.N (2006). Narodnye predstavleniia slavian [Ethnic Beliefs of the Slaves]. Moscow, 648 p.

Watkins, C. (1987). Linguistic and archeological light on some Homeric formulas. Proto-Indo-European: the archeology of linguistic problem studies in honour of Maria Gimbutas: 286-98; Washington. (DC): Institute for the Study of Man.

Watkins, C. (1995). How to kill a dragon. Aspects of Indo-European poetics. Oxford University Press, $613 \mathrm{p}$. 


\title{
Интерпретации мифологемы «дерево-крест» в древнеанглийской традиции
}

\author{
С.Г. Проскурина, ${ }^{a, 6}$ А.В. Проскурина \\ ${ }^{a}$ Новосибирский национальный исследовательский \\ государственный университет \\ Российская Федерачия, Новосибирск \\ ${ }^{6}$ Новосибирский государственный технический университет \\ Российская Федерачия, Новосибирск
}

\begin{abstract}
Аннотация. Актуальность обращения к интерпретации мифологемы «деревокрест» вызвано переломным характером эпохи смены языческого мировоззрения христианским. Развитие представлений о христианском знаке носит сложный характер, в одном из подходов в преобразовании дерево-крест сохраняется часть преодоленных знаний о мире как пространстве вокруг мировой оси, т.е. мировом древе. Наступившая эпоха христианства наследует это знание, а сам крест предстает мировой осью, определяющей координаты пространства. Цель статьи показать эволюционный семиотический ряд, который представляет христианскоязыческую символику. Изначально крест возникает как мотивированный образ. Затем появляются термины денотативного плана, лишенные языческих коннотаций типа cross.

В целом, в эволюции термина прослеживается преемственность, одно обозначение заменяется другим. В течение некоторого времени второй предмет копирует функции и формы первого, замещая его в предметном ряду. Крест как предмет поклонения в христианстве замещает мировое дерево. Все новые номинации креста связываются с мотивированностью мира как центра, где установлен алтарь, который изначально представлялся в традиции мировым деревом, а затем стал обозначаться крестом. Крест как главный христианский символ часто предстает как сделанный из дерева и идентифицируется с космическим мировым древом, растущим прямо в небеса. Методы исследования - филологический анализ текста и семиотический подход к анализу текстов. Во внимание принимается совокупность коммуникативно-релевантных факторов, обуславливающих высказывание, а также ситуативная и контекстная отнесенность лексического значения. В свою очередь, необходимый исходный объем коммуникативно-релевантной информации получен на основе лингвистических методов. В частности, привлекаются данные этимологического анализа. Материалом исследования послужили доступные современному исследователю древнеанглийские письменные памятники. Тексты на других индоевропейских языках привлекаются эпизодически, они выступают в качестве фона, демонстрирующего некоторые параллели.
\end{abstract}

Ключевые слова: крест, мировое древо, эволюционный семиотический ряд, язычество, христианство, мифологема.

Научная специальность: 10.02.00 - языкознание. 